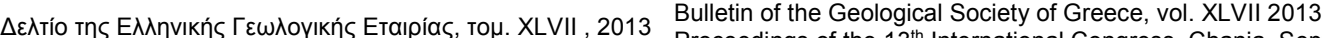

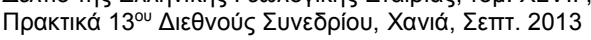

\title{
OCCURRENCE OF ARSENIC IN WATERS AND SEDIMENTS OF THE PALEA KAVALA RIVER, NE MACEDONIA, NORTHERN GREECE
}

\author{
Giouri K. ${ }^{1}$, Vavelidis M. ${ }^{1}$ and Melfos V. ${ }^{1}$ \\ ${ }^{1}$ Department of Mineralogy-Petrology-Economic Geology, Faculty of Geology, Aristotle \\ University of Thessaloniki,agiouri@geo.auth.gr
}

\begin{abstract}
Inorganic arsenic (As) is a naturally occurring metal, present in various ecosystems. However, it can also be added to an aquatic system by anthropogenic activities. The aim of the present study is to determine the total As content in the Palea Kavala river (NE Macedonia, Northern Greece). The correlation between As content and some chemical and physico-chemical parameters of the samples was also examined. Research demonstrated significant As concentrations in the water and the sediments of the river. No correlation was found between As and $\mathrm{pH}, \mathrm{Fe}, \mathrm{Mn}$ in the water samples. Concerning the sediment samples, positive correlation was revealed for As with $\mathrm{Fe}$ and Mn content, while negative correlation was revealed between As and $p H$. This is probably indicative of a higher arsenic mobility in the Palea Kavala river water than in sediments. Since no anthropogenic activities were observed in the river's catchment area, elevated As concentrations are probably due to the lithology of the broader area and especially the presence of extended ore mineralizations including As-bearing sulphide minerals. However, the research in the study area is in progress since a more detailed evaluation of the local sources of As and mechanisms of As release is required.
\end{abstract}

Key words: Inorganic contamination, heavy metals, Northern Greece.

\section{Пєрí $\eta \Psi \psi \eta$}

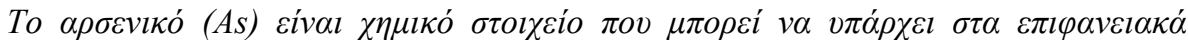

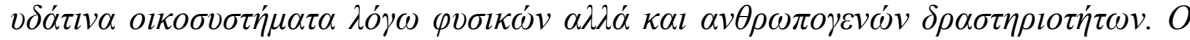

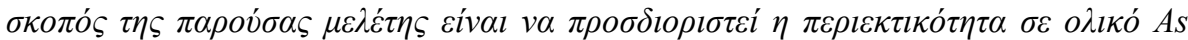

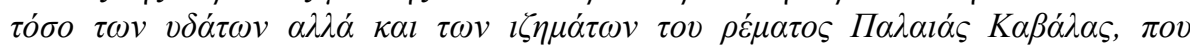

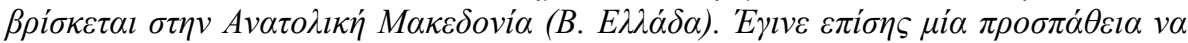

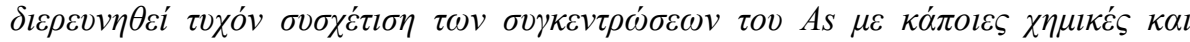

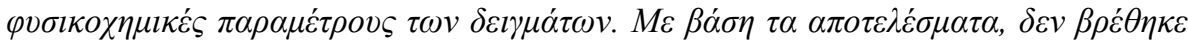

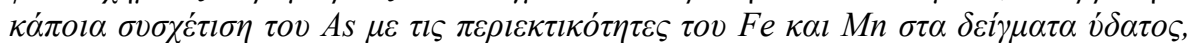

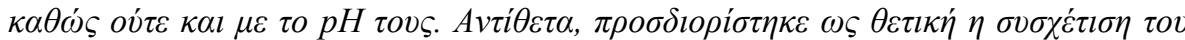

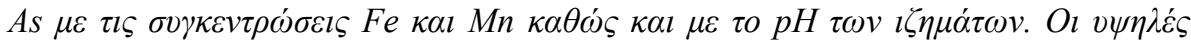

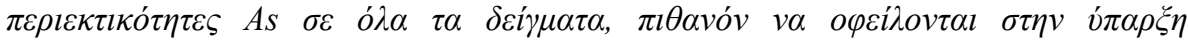

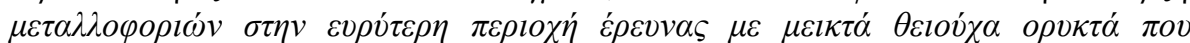

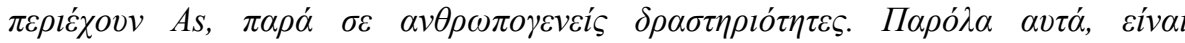

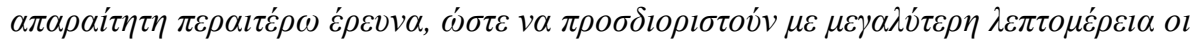

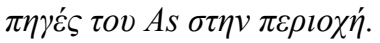

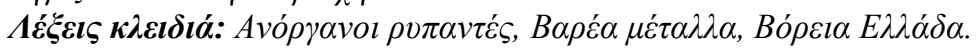

$\underline{\text { XLVII. No } 2-934}$ 


\section{Introduction}

Trace elements, especially heavy toxic metals, in surface waters are attributed to natural or anthropogenic sources. In elevated concentrations, toxic metals may lead to irreversible health diseases. For this reason, the pollution of the surface aquatic systems, especially rivers, with inorganic pollutants has been attracting the attention of public and scientific community over the last few decades (Kabata-Pendias and Pendias, 2001; Suthar et al., 2009). A naturally occurring element in ecosystems is inorganic arsenic (As). It occurs in a variety of environmental media, including minerals, rocks, sedimentary deposits, soil, water and plants and usually is incorporated in sulfide minerals. Nevertheless, arsenic can also originate from anthropogenic activities and transmitted in the environment as a contaminant through sewage discharge or use of fertilizers in agriculture (Nordstrom, 2002; Hoang et al., 2010).

Arsenic contamination in water has caused severe health problems around the world, since it causes serious natural hazards when exceeding the established standards. The association between arsenic and human health effects is well described by numerous related surveys globally. Furthermore, the chemical analysis of river sediments is very useful when studying inorganic contamination in an area (Förster and Salomons, 1991; Abernathy et al., 2003 and references therein).

The objective of the present study is to determine the presence of the total arsenic content in water and sediments of the Palea Kavala river and examine if there is any correlation with chemical and physico-chemical parameters of the samples. Palea Kavala river is located $6 \mathrm{~km}$ north of the Kavala city, in northeastern Greece (Figure 1). It emanates from the Lekani mountains and passing through the Palea Kavala village it flows towards the Philippoi plain. When entering the plain, due to the extensive karst formations, the river disappears into the sediments.

\section{Geological Setting}

Geologically the study area belongs to the lower Pangeon unit of the Rhodope massif, consisting mainly of gneisses overlain by marbles. In the Palea Kavala area the metamorphic rocks of the Rhodope massif, were intruded by the Kavala pluton of a Lower Miocene age (21-22 Ma). The latter has the characteristics of an I-type intrusion and is mainly composed of amphibole-biotite granodiorite. Alluvial deposits which consist of clays, sands and gravels overlie the crystalline rocks (Kronberg, 1970; Kronberg and Melidonis, 1970; Christofides, 1996; Vavelidis et al., 1997; Melfos et al., 2008) (Figure 1).

The Palea Kavala region contains $\sim 150$ minor hydrothermal-magmatic base- and precious-metal occurrences within the Kavala pluton and the surrounding metamorphic rocks of the Rhodope massif. These occurrences have variable metal assemblages that include Fe-Mn-( $\mathrm{Pb} \pm \mathrm{Zn} \pm \mathrm{Ag}), \mathrm{Fe}-$ $\mathrm{Mn}-\mathrm{Au}, \mathrm{Fe}-\mathrm{As}-\mathrm{Au}, \mathrm{Fe}-\mathrm{Cu}-\mathrm{Au}$ and $\mathrm{Bi}-\mathrm{Te}$, but most are weathered and oxidized. Primary metallic minerals consist of pyrite, arsenopyrite, chalcopyrite, pyrrhotite, galena, sphalerite, tetrahedritetennantite, petzite, bismuthinite, tetradymite, cosalite, bismuthinite, lillianite, proustite, pyrargyrite, argentite, jalpaite, stephanite and native gold. Arsenic is mainly related with arsenopyrite, proustite and tennantite (Vavelidis et al., 1996a,b; Melfos et al., 2008; Fornadel et al., 2011).

\section{Materials and Methods}

\subsection{Sample Collection}

Seven sites were sampled for water (PKW1 to PKW7) and thirteen sites for their sediments (PK1 to PK13) downstream the Palea Kavala river (Figure 1). Water and sediment sampling was carried out in November 2009, after the dry season, and in May 2010, after the rainy season, leading to fourteen in total water samples. 
Water sampling was performed with plastic bottles of $300 \mathrm{ml}$ capacity, rinsed with distilled water. Following that, the samples were delivered on the same day to the laboratory. Sediment samples were collected at the top of the riverbeds and their banks, avoiding the input of other materials. All sediment samples were collected with a plastic shovel and were put in plastic bags.

\subsection{Laboratory Treatment of Samples}

The water samples were filtered through $0.45 \mu \mathrm{m}$ Whatman filter paper, acidified with $\mathrm{HNO}_{3}(1: 1)$ to $\mathrm{pH} 2$, and stored at $4^{\circ} \mathrm{C}$ in polyethylene plastic bottles until they were sent for analysis.

At the laboratory, after the removal of organic material, sediment samples were dried in an oven at $60^{\circ} \mathrm{C}$. They were gently ground with rolling pin to disaggregate the samples but not break down the grains themselves, sieved to collect less than $0.063 \mathrm{~mm}$ grain size and stored in polyethylene bags until they were sent fir analysis. The $<0.063 \mathrm{~mm}$ fraction was used due to the fact that the environmentally available trace elements mainly remain in this fraction, because of its larger specific area. Therefore, fine sediments have been used by many researchers in order to investigate river pollution (Kabata-Pendias and Pendias, 2001; Salomons, 1995).

\subsection{Sample Analysis}

The physico-chemical parameter $\mathrm{pH}$ of the water was measured in the field during sampling, using a portable combined instrument. The $\mathrm{pH}$ of sediments was measured at the laboratory using a digital pH-meter. The chemical analyses were performed at the Acme Analytical Laboratories (Vancouver, Canada). Metals in the sediments were extracted using the aqua regia digestion, while their concentrations were determined in all samples by ICP-MS.

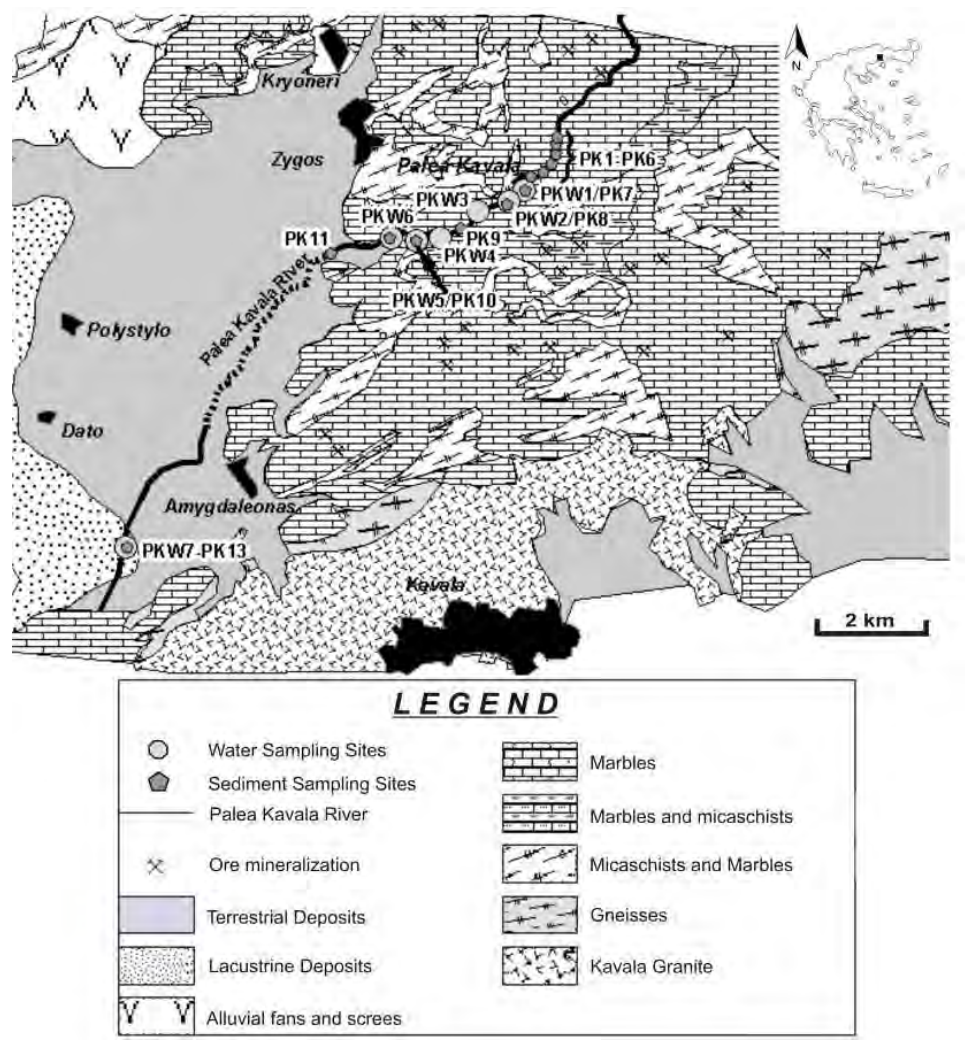

Figure 1 - Geological map of the studied area with the Palea Kavala river and sampling sites (according to Kronberg, 1970; Kronberg and Melidonis, 1970 with modifications).

$\underline{\text { XLVII. No } 2-936}$ 


\section{Results and Discussion}

The results of the physico-chemical analyses and of heavy metals content in water and sediment samples are shown in Table 1 and Table 2, respectively. The $\mathrm{pH}$ values were approximately neutral to slightly alkaline, with a range of 7.36 to 8.14 . The range of concentration for As and $\mathrm{Mn}$ in the water samples was 15.9- 59.9 ppb and 0.5-152 ppb, respectively.

Arsenic content after the wet season ranges from 28.9 to $59.9 \mathrm{ppb}$, and after the dry season from 15.9 to $37.4 \mathrm{ppb}$. This demonstrates that arsenic levels after the dry season (November 2009) are higher than the respective ones which followed the wet season (May 2010). It is apparent, therefore, that arsenic contents were higher during the period of a low river flow (Figure 2). This has also been confirmed by previous studies (Giouri et al., 2012), according to which significant variations of As content were found in most of the sites. However, clear trends in these changes between wet and dry season were not determined, as it was also concluded by the coefficient of determination $(\mathrm{R} 2)$. According to its value $(\mathrm{R} 2=0.60)$ there was found a positive but moderate correlation between wet and dry season As concentrations.

Table 1 - Results of the $\mathrm{pH}$ and the As, Mn concentrations in surface waters of the Palea Kavala river.

\begin{tabular}{|c|r|r|c|c|}
\hline Number of samples & & $\mathrm{pH}$ & $\begin{array}{c}\mathrm{As} \\
(\mathrm{ppb})\end{array}$ & $\begin{array}{c}\mathrm{Mn} \\
(\mathrm{ppb})\end{array}$ \\
\hline \multirow{2}{*}{$\begin{array}{c}\mathrm{n}=14 \\
(\text { PKW1a-PKW7a } \rightarrow \text { Nov-2009) }\end{array}$} & $\min$ & 7.36 & 15.9 & 0.5 \\
\cline { 2 - 5 }$($ mKW & 8.14 & 59.9 & 152.0 \\
\cline { 2 - 5 } & median & 7.63 & 35.9 & 2.8 \\
\cline { 2 - 5 } & mean & 7.71 & 38.7 & 22.7 \\
\hline
\end{tabular}

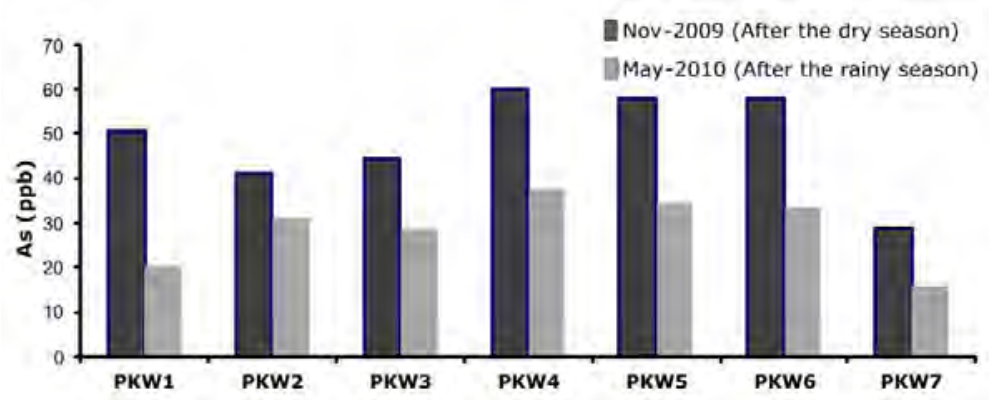

Figure 2 - Variation in the concentrations of As in the water samples collected downstream $P$ alea Kavala river, for both sampling periods.

Table 2 - Results of the $\mathrm{pH}$ and the As, Mn, Fe concentrations in the sediments of the Palea Kavala river.

\begin{tabular}{|c|r|c|c|c|c|}
\hline Number of samples & & $\mathrm{pH}$ & $\begin{array}{c}\mathrm{As} \\
(\mathrm{ppm})\end{array}$ & $\begin{array}{c}\mathrm{Mn} \\
(\mathrm{ppm})\end{array}$ & $\begin{array}{c}\mathrm{Fe} \\
(\mathrm{wt} \%)\end{array}$ \\
\hline \multirow{3}{*}{$\begin{array}{c}\mathrm{n}=13 \\
(\mathrm{PK} 1-\mathrm{PK} 13)\end{array}$} & $\min$ & 6.33 & 51.3 & 405 & 1.6 \\
\cline { 2 - 6 } & $\max$ & 8.18 & 705.5 & 5268 & 4.0 \\
\cline { 2 - 6 } & median & 7.58 & 170.1 & 822 & 3.6 \\
\cline { 2 - 6 } & mean & 7.37 & 231.0 & 1097 & 3.1 \\
\hline
\end{tabular}


The $\mathrm{pH}$ values of the sediments range from 6.33 to 8.18 , without any drastic differences among sampling sites. As and Mn concentrations are high in all samples, ranging from 51.3 to $705.5 \mathrm{ppm}$ and from 405 to $5268 \mathrm{ppm}$, respectively. Fe was also relatively high varying from 1.6 to $4.0 \mathrm{wt} \%$ (Table 2 and Figure 3). From the diagram in Figure 3, it can be concluded in general that the variation in As concentrations, follow the variations of $\mathrm{Mn}$ and $\mathrm{Fe}$.

The distribution of As in water and sediments of surface streams or rivers, is related with the $\mathrm{pH}$, the deliberate pollution and the release of other compounds which can adsorb arsenic. In the case of rivers, the As content may be strongly affected by geological characteristics of the drainage area of the rivers and by anthropogenic inputs. The adsorption of As on precipitated hydrous Fe and Mn oxides that exist in the sediments of the rivers, is significant. It is apparent, therefore, that the correlation between the content of $\mathrm{As}, \mathrm{Mn}$ and $\mathrm{Fe}$ in the collected water and sediment samples should be further studied (McLaren and Kim, 1995; Smedley, P.L. and Kinniburgh, D.G., 2002; Gault et al., 2003; Sanchez-Rodas et al., 2005; Nordstrom, 2011; Sarmiento et al., 2012).

According to the water analyses results in Palea Kavala river, the relationship between As content and $\mathrm{pH}$ is weak but negative (Figure 4 ) with a correlation coefficient factor $\mathrm{R}^{2}=0.18$. Similarly the correlation of As with $\mathrm{Mn}$ is also very poor, with $\mathrm{R}^{2}=0.0051$ (Figure 4). Arsenic in water is also very poorly correlated with Fe. According to the present study, Fe in most of the samples was below detection limits, with the exception of 2 samples (data not shown). This means that there is not any relationship between As and $\mathrm{Fe}$ and therefore As in the water is not adsorbed because of the presence of $\mathrm{Fe}$.

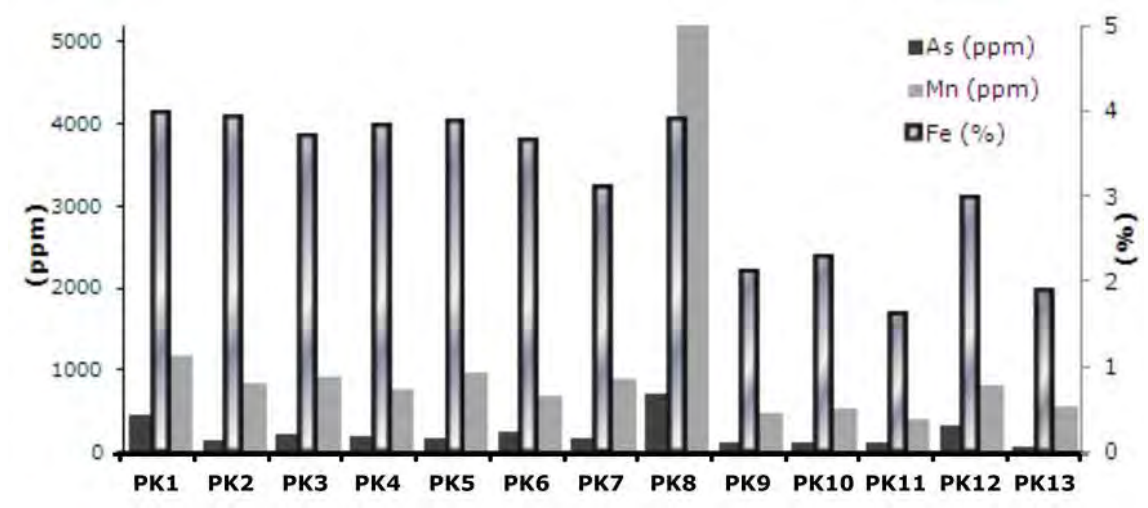

Figure 3 - Variation in the concentrations of As, Mn and Fe in the sediment samples collected downstream Palea Kavala river.
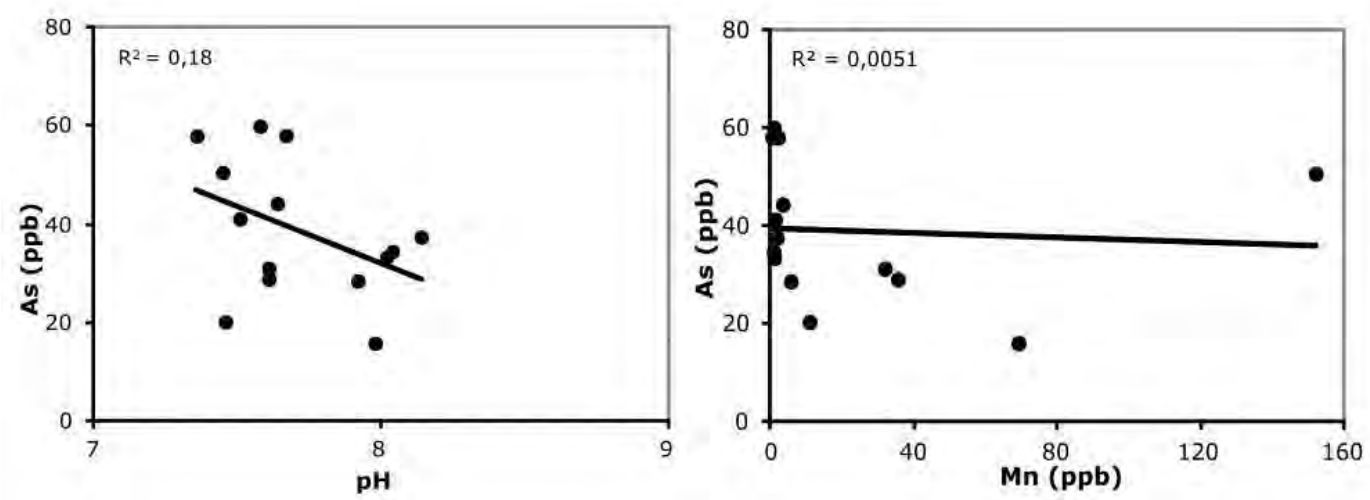

Figure 4 - Scatter plot of arsenic concentrations in the water sample in correlation with pH and Mn content.

XLVII, No $2-938$ 
According to the results of sediment analyses (Figure 5), a moderate negative correlation was observed between arsenic and $\mathrm{pH}\left(\mathrm{R}^{2}=0.41\right)$. The correlation of As is stronger with $\mathrm{Mn}$ than with Fe. This is concluded since the value of correlation coefficient factor for As with $\mathrm{Mn}$ is $\mathrm{R}^{2}=0.77$, while for As with $\mathrm{Fe}$ is $\mathrm{R}^{2}=0.30$. It should be mentioned that the sample with the most elevated concentrations of $\mathrm{As}$ and $\mathrm{Mn}$ is not plotted close to the rest ones (Figure 5). However, by exempting that specific sample, the correlation between $\mathrm{As}$ and $\mathrm{Mn}$ is slightly weaker $\left(\mathrm{R}^{2}\right.$ decreases from 0.77 to 0.54 ), remaining still positive and relatively good. As illustrated in Figures 4 and 5, arsenic shows a closer relationship with $\mathrm{pH}, \mathrm{Fe}$ and $\mathrm{Mn}$ in the sediments than with the corresponding parameters in water.

Since in the catchment area of Palea Kavala river any anthropogenic activities were not observed, which as a consequence can increase metal concentrations in the sediment and water, it is assumed that high arsenic content can be attributed to the geological environment. After all, some of the primary minerals that comprise the metal assemblages occurring in the Palea Kavala region, mainly arsenopyrite, proustite and tennantite (Fornadel et al., 2011), are related with the elevated As concentrations. This is also demonstrated in Figure 6, since it is revealed that higher concentrations of As are observed mainly upstream Palea Kavala river, where the majority of Asbearing ore mineralizations occur.

\section{Conclusions}

The purpose of the present study was to determine the total arsenic content in water and sediments of the Palea Kavala river (NE Macedonia, Northern Greece). Furthermore, it was examined if there is any correlation between As and some chemical and physico-chemical parameters in the samples.

Results of chemical analyses demonstrated considerable concentrations of As, both in water and sediments of the river. This is probably due to some geological factors such as the lithology of the broader area. Especially the presence of extended ore mineralizations which include arsenopyrite $(\mathrm{FeAsS})$, proustite $\left(\mathrm{Ag}_{3} \mathrm{AsS}_{3}\right)$ and tennantite $\left((\mathrm{Cu}, \mathrm{Ag}, \mathrm{Fe}, \mathrm{Zn})_{12}(\mathrm{As}, \mathrm{Sb})_{4} \mathrm{~S}_{13}\right)$ in metal occurrences in Palea Kavala region, and so in the river water and sediments because of weathering and transportation, can be related with As content.

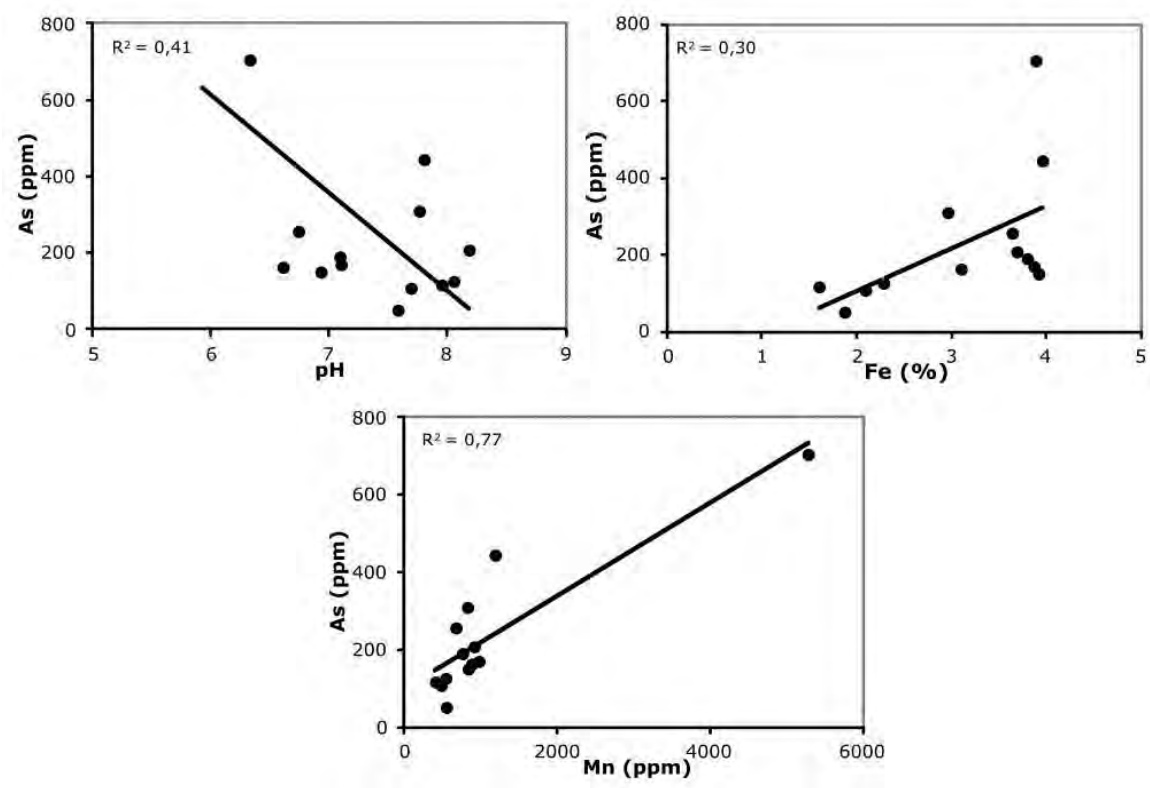

Figure 5 - Scatter plot of arsenic concentrations in every sediment sample in correlation with pH, Fe and Mn content.

XLVII. No 2 - 939 


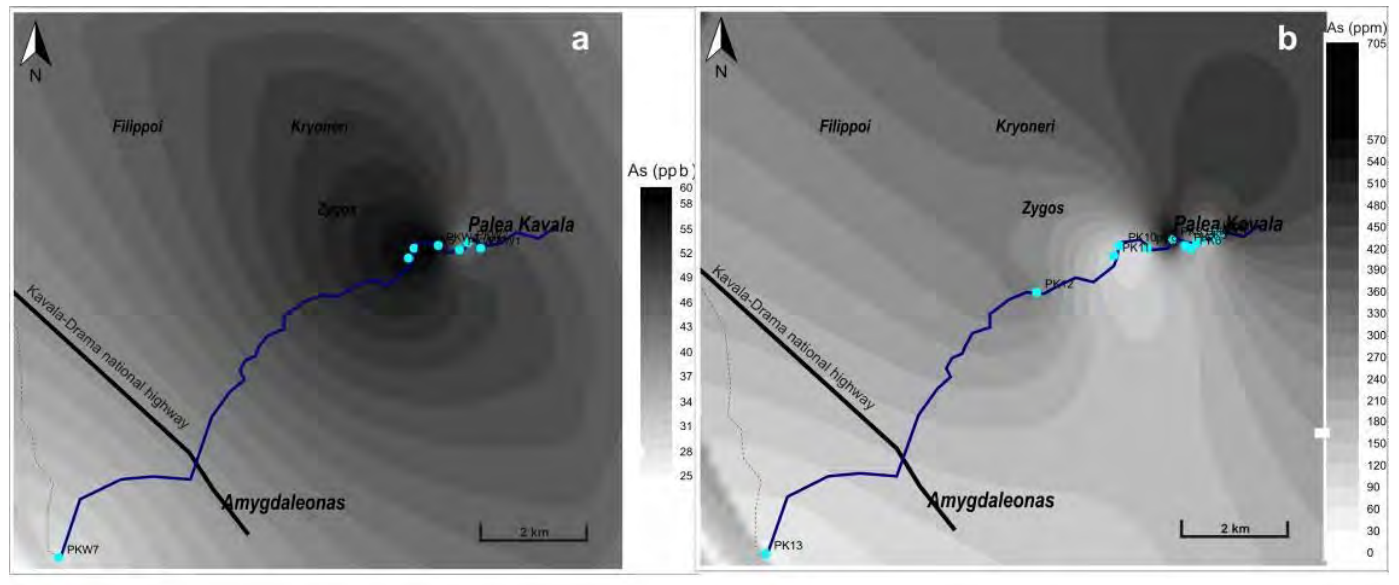

Figure 6 - Spatial distribution of $\mathbf{A s}_{(\mathrm{tot})}$ in the water (a) and sediments (b) of Palea Kavala river.

Physicochemical factors such as $\mathrm{pH}$ and the presence of $\mathrm{Mn}$ and Fe oxides, can contribute to the adsorption of As. However, no correlation was found between As content and $\mathrm{pH}$, as well as $\mathrm{Fe}$ and $\mathrm{Mn}$ in the water samples. On the other hand, positive correlation was revealed for As with $\mathrm{Fe}$ and $\mathrm{Mn}$ and negative correlation was observed between $\mathrm{As}$ and $\mathrm{pH}$ in the sediments. It can probably be concluded that mobility of arsenic in Palea Kavala river is higher in water than in sediments. However, the research in the study area is in progress since a more detailed evaluation of the local sources of As and mechanisms of As release in surface water is required.

\section{Acknowledgements}

The first author (Giouri K.) would like to thank the State Scholarships Foundation of Greece for the financial support during her post-graduate studies. The authors would like to thank P. Voudouris, an anonymous reviewer and the associated editor for their constructive comments and recommendations.

\section{References}

Abernathy C.O., Thomasy D.J. and Calderon R.L. 2003. Toxicity and risk assessment of trace elements. Health effects and risk assessment of arsenic, Am. Soc. Nutr. Sci., 1536-1538.

Christofides G. 1996. Tertiary magmatism in the Greek Rhodope Massif, northern Greece: Granitic plutons, in Knezevic V., Krstic B. (eds.), Terranes of Serbia: The Formation of the Geologic Framework of Serbia and the Adjacent Regions. University of Belgrade, Belgrade, $155-160$.

Fornadel A.P., Spry, P.G., Melfos V., Vavelidis M. and Voudouris P.Ch. 2011. Is the Palea Kavala $\mathrm{Bi}-\mathrm{Te}-\mathrm{Pb}-\mathrm{Sb} \pm \mathrm{Au}$ district, northeastern Greece, an intrusion-related system? Ore. Geol. Rev., 39, 119-133.

Förster U. and Salomons W. 1991. Mobilization of metals from sediment, in Merian, E. (eds), Metals and their compounds in the environment, VCH, Weinheim, 379-398.

Gault A.G., Polya D.A. and Lythgoe P.R. 2003. Seasonal variation of total dissolved arsenic and arsenic speciation in a polluted waterway, Environ. Geochem. Health, 25, 77-85.

Giouri A., Vavelidis M. and Melfos V. 2012. Primary approach on the evaluation of total arsenic concentration in Palea Kavala river, NE Macedonia, Northern Greece, Proc. of the XI Protection and Restoration of the Environment International Conference, Thessaloniki, 3-6 July, 356-364. 
Hoang T.H., Bang S., Kim K.W., Nguyen M.H. and Dang D.M. 2010. Arsenic in groundwater and sediment in the Mekong River delta, Vietnam. Environ. Pollut., 158, 2648-2658.

Kabata Pendias A. and Pendias H. 2001. Trace elements in soils and plants, $3^{\text {rd }}$ ed. CRC Press, Boca Raton, Florida, 413p.

Kronberg P. and Melidonis N. 1970. Geological map of Greece, Krinidhes Sheet, Scale 1:50.000. IGME, Athens.

Kronberg P. 1970. Geological map of Greece, Kavala Sheet, Scale 1:50.000. IGME, Athens.

McLaren S.J. and Kim N.D., 1995. Evidence for a seasonal fluctuation of arsenic in New Zealand's longest river and the effect of treatment on concentrations in drinking water. Environ. Pollut., 90 (1), 67-73.

Melfos V., Voudouris P., Vavelidis M. and Spry, P.G. 2008. Microthermometric results and formation conditions of a new intrusion-related $\mathrm{Bi}-\mathrm{Te}-\mathrm{Pb}-\mathrm{Sb} \pm \mathrm{Au}$ mineralization in the Kavala Pluton, Greece. Joint 13th All-Russian Conference on Thermobarogeochemistry/ 4th Asian and Pacific International Fluid Inclusion Society Symposium, Moscow, Abstracts.

Nordstrom D.K. 2002. 'Public health. Worldwide occurrences of arsenic in ground water, Science, 296, 2143-2145.

Nordstrom D.K. 2011. Hydrogeochemical processes governing the origin, transport and fate of major and trace elements from mine wastes and mineralized rock to surface waters, Appl. Geochem., 26, 1777 - 1791.

Salomons W. 1995. Environmental impact of metals derived from mining activities: processes, predictions, preventions, J. Geochem. Explor., 52, 5-23.

Sanchez-Rodas D., Gomez-Ariza J.L., Giraldez I., Velasco A. and Morales E. 2005. Arsenic speciation in river and estuarine waters from Southwest Spain, Sci. Total Environ., 345, 207-217.

Sarmiento A.M., Caraballo M.A., Sanchez-Rodas D., Nieto J.M. and Parviainen A. 2012. Dissolved and particulate metals and arsenic species mobility along a stream affected by Acid Mine Drainage in the Iberian Pyrite Belt (SW Spain), Appl. Geochem., 27, 1944-1952.

Smedley P.L. and Kinniburgh D.G. 2002. A review of the source, behavior and distribution of arsenic in natural waters, Appl. Geochem., 17, 517-568.

Suthar S., Nema K.A., Chabukdhara M. and Gupta K.S. 2009. Assessment of metals in water and sediments of Hindon River, India: Impact of industrial and urban discharges, J. Hazard. Mater., 171, 1088-1095.

Vavelidis M., Christofides G. and Melfos, V. 1996a. The Au-Ag-bearing mineralization and placer gold of Palea Kavala (Macedonia, N. Greece). In Knežević-Dorđević, V., Krstić, B. (eds.), Terranes of Serbia: The Formation of the Geologic Framework of Serbia and the Adjacent Regions. University of Belgrade, Belgrade, 311-316.

Vavelidis M., Gialoglou G., Melfos V. and Wagner G.A. 1996b. Goldgrube in Palaea KavalaGriechenland: Entdeckung von Skaptehyle? Erzmetall, 49, 547-554.

Vavelidis M., Melfos, V. and Eleftheriadis G. 1997. Mineralogy and microthermometric investigations in the Au-bearing sulphide mineralization of Palea Kavala (Macedonia, Greece). In Papunen, H. (eds.), Mineral Deposits: Research and Exploration - Where do They Meet? Balkema, Rotterdam, 343-346. 